\title{
PENGGUNAAN DESIGN INTRUKSIONAL MODEL ASSURE PADA MATERI PENDIDIKAN AGAMA ISLAM DI MI DARUL HIDAYAH TIRTOYUDO
}

\author{
Ning Fina Inayatus Sofa \\ Universitas Islam Negeri Sunan Ampel Surabaya \\ e-mail: finainayatussofa@gmail.com
}

Diterima: 13 Mei 2020 | Direvisi: 24 Mei 2020 | Disetujui: 25 Mei 2020

(C) 2018 Program Studi Pendidikan Agama Islam Fakultas Agama Islam Universitas Islam Malang

\begin{abstract}
In determining the learning design teachers must pay attention to learning models that fit the needs of students, so they can help the learning process that is good, effective and efficient. This study aims to illustrate the use of instructional design model learning in PAI materials at MI Darul Hidayah Tirtoyudo, describe the obstacles faced by the use of convincing design learning models on PAI material, and describe solutions to overcome the obstacles encountered. The method used is a qualitative approach to the type of evaluation research, while data collection techniques use observation and interviews. The results of this study are: 1) the use of design learning models assure strongly supports the teaching and learning process and can motivate students to increase their potential, 2) the obstacle faced is the presence of some students who are lazy to learn so they need supervision additional to the teacher, there are delays $A B K$ students in understanding the subject matter, 3) solutions to overcome obstacles namely, teachers can work together with psychologists in order to find out the cause of student laziness, so they can find solutions. While solutions for special needs students can be handled by teachers through a comprehensive learning approach.
\end{abstract}

Keywords: Design, Instructional, Model Assure

\begin{abstract}
Abstrak
Dalam menentukan desain pembelajaran guru harus memperhatikan model pembelajaran yang sesuai dengan kebutuhan siswa, sehingga mereka dapat membantu proses pembelajaran yang baik, efektif dan efisien. Kajian ini bertujuan menggambarkan penggunaan pembelajaran desain model instruksional dalam bahan PAI di MI Darul hidayah Tirtoyudo, menggambarkan kendala yang dihadapi dengan penggunaan model pembelajaran desain yang meyakinkan pada materi PAI, serta menggambarkan solusi untuk mengatasi kendala yang dihadapi. Metode yang digunakan adalah pendekatan kualitatif terhadap jenis penelitian evaluasi, sedangkan teknik pengumpulan data menggunakan pengamatan dan wawancara. Hasil studi ini adalah: 1) penggunaan model pembelajaran assure sangat mendukung proses pengajaran dan pembelajaran dan dapat
\end{abstract}


memotivasi siswa untuk meningkatkan potensi mereka, 2) hambatan yang dihadapi adalah kehadiran beberapa siswa yang malas untuk belajar sehingga mereka membutuhkan pengawasan tambahan dari guru, ada penundaan siswa $A B K$ dalam memahami materi pelajaran ,3) solusi untuk mengatasi rintangan yaitu, guru dapat bekerja sama dengan psikolog dalam rangka untuk mengetahui penyebab kemalasan siswa, sehingga mereka dapat menemukan solusi. Sementara solusi bagi siswa ABK dapat ditangani oleh guru melalui pendekatan pembelajaran yang komprehensif.

Kata Kunci: Desain, Instruksional, Model Assure

\section{Pendahuluan}

Tujuan pendidikan agama islam (PAI) adalah mendidik siswa agar berprilaku sesuai nilai-nilai ajaran agama yakni agama islam yang di jadikan pedoman dalam berkehidupan. Oleh karena itu guru sebagai penopang ilmu pengetahuan yang akan di sampaikan kepada peserta didik seharusnya bisa memberikan pengertian hakikat beragama terhadap peserta didik dengan cara mempunyai wawasan yang luas seiring dengan perkembangan zaman, yakni guru harus mampu mendesain pembelajaran yang efektif sehingga peserta didik dengan mudah memahami materi yang di sampaikan guru dalam proses pembelajaran.

Dalam proses pembelajaran diperlukan penggunaan media, metode, strategi, bahan ajar yang tepat yang artinya dalam mendesain pembelajaran harus kompatibel dengan individu maupun kelompok peserta didik, dalam hal ini gurulah yang mempunyai tugas utama sebagai pendidik. Karena proses pelaksanaan belajar mengajar yang tiada lain gurulah yang menjadi faktor utama dalam penentuan kegiatan pembelajaran.

Begitu juga dalam mentransfer ilmu pengetahuan terhadap peserta didik seorang guru harus memperhatikan pelaksanaan pembelajaran dengan menyusun rencana proses pembelajaran. Dalam proses pembelajaran guru juga harus bisa menyesuaikan dengan keadaan atau karakteristik peserta didik, selain itu seharusnya dapat membawa siswa supaya aktif dalam pembelajaran, karena guru mempunyai peran sebagai fasilitator dalam sebuah pembelajaran, untuk itu haruslah dilaksanakan secara interaktif, inspiratif, menyenangkan dan dapat mendorong kreativitas siswa. Sehingga tentunya harus memperhatikan beberapa desain pembelajaran, seperti hal nya dalam memilih model pembelajaran seorang pendidik dapat memilih model pembelajaran yang sesuai dengan kebutuhan pembelajaran agar mencapai tujuan pendidikannya ( ${ }^{1}$ (Salamah Zainiyati, 2010)). 
Model assure sebagai sebuah desain pembelajaran yang sederhana dan mudah di aplikasikan sehingga sering di gunakan dalam kegiatan belajar mengajar di kelas. Selain itu model assure merupakan acuan sebagai pedoman dalam memilih media, metode dan bahan ajar yang akan di pakai dalam pembelajaran agar terciptanya pembelajaran yang efektif dan efisien.

MI Darul Hidayah merupakan lembaga pendidikan yang mana setiap pembelajaran sering melakukan proses belajar di luas kelas, yakni peserta didik di ajak ke dunia nyata untuk mempelajari hakikat pendidikan. Dalam rangka meningkatkan hasil belajar pendidikan agama islam (PAI) di MI Darul Hidayah Tirtoyudo dalam mendesain pembelajaran menggunakan model assure dan menggunakan berbagai metode belajar seperti demonstrasi, diskusi, pemecahan masalah dan metode lainnya sesuai dengan kebutuhan proses pembelajaran. Dengan beberapa metode dan media yang di pakai di harapkan desain pembelajaran berguna dan efektif digunakan dalam pembelajaran dan menghasilkan hasil yang maksimal sesuai tujuan pembelajaran.

Sesuai dengan latar belakang di atas peneliti bertujuan untuk (1) mendeskripsikan penggunaan desain pembelajaran model assure pada materi PAI di MI Darul Hidayahtirtoyudo, (2) mendeskripsikan kendala yang di hadapi dalam penggunaan desain pembelajaran model assure pada materi PAI di MI Darul Hidayah Tirtoyudo, (3) mendeskripsikan solusi untuk mengatasi kendala yang di hadapi dalam penggunaan desain pembelajaran model assure pada materi PAI di MI Darul Hidayah Tirtoyudo

\section{Metode}

Metode yang digunakan dalam penelitian ini yaitu pendekatan kualita tif dengan jenis penelitian evaluasi kualitatif. Dalam penelitian ini bertujuan untuk mengetahui gambaran mengenai penggunaan desain pembelajaran model assure pada materi PAI di MI Darul Hidayah Tirtoyudo pada materi agama islam. Pengambilan sampel sumber data selain dilakukan secara purposive yaitu siswa kelas 4, 5 dan 6 MI Darul Hidayah, juga dilakukan secara snowball dengan tujuan mencari data yang terkait dengan kepala sekolah, dan 2 guru pai yang menggunakan desain pembelajaran model assure dalam pembelajaran. pengumpulan data pada penelitian ini menggunakan teknik wawancara dan observasi dengan memakai tipe wawancara bebas terpimpin yang digunakan sebagai alat wawancara kepada kepala sekolah, peserta didik, guru PAI dan guru kelas .

\section{Pembahasan}


Pembahasan hasil penelitian ini yakni akan memaparkan terkait data yang di peroleh di MI Darul Hidayah melalui observasi dan wawancara, berikut ini merupakan uraian dari penggunaan desain pembelajaran model assure dalam pembelajaran di sekolah tersebut.

Berdasarkan hasil observasi di MI Darul Hidayah Tirtoyudo dalam proses belajar mengajar guru sering membawa peserta didik ke luar kelas, yakni membawanya ke tempat yang sesuai dengan materi belajar. Sesuai dengan judul penelitian ini peneliti berfokus pada materi PAI yang di ajarkan guru. Pada saat itu bertepatan dengan materi bab rukun islam yakni materi mempraktekkan serta membaca doa wudhu pada kelas 2, dan bab macam-macam sholat pada kelas 3 dan bab membiasakan ahlak terpuji pada kelas 4. Dalam hal ini penulis meneliti pembelajaran PAI dari mulai kelas 2 sampai dengan kelas 4 MI karena bertepatan guru yang memakai model assure dalam pembelajaran mengaplikasikan pada proses belajar di kelas tersebut.

Pertama, terkait kebijakan kepala sekolah dengan adanya penggunanaan design intruksional model assure dalam proses pembelajaran berdasarkan hasil wawancara peneliti sebagai berikut:

Kepala sekolah mendukung hal tersebut yaitu dengan mengijinkan guru untuk mendesain pembelajaran dengan melaksanakan kegiatan proses belajar di kelas maupun di luar kelas, karena untuk anak mi pun juga menginginkan kegiatan belajar yang sekiranya dapat membangkitkan motivasi belajar peserta didik di antaranya dengan menggunakan model assure tersebut yang di susun oleh guru dan di sesuaikan dengan kebutuhan siswa.

Selanjutnya peneliti juga melakukan wawancara dengan narasumber kedua yaitu Ibu Ainin, tentang penggunaan model assure dalam proses pembelajaran selaku guru PAI di MI Darul Hidayah sebagai berikut:

Terkait desain pembelajaran model assure yang digunakan dalam pembelajaran sangat mendukung proses pembelajaran karena model assure merupakan model pembelajaran yang sederhana dan mudah kita gunakan dalam pembelajaran seperti halnya pada materi pai bab mengenal macam-macam sholat dalam proses belajar para siswa kami bimbing tentang pengetahuan materi sholat dan mempraktikkannya langsung di masjid tidak di dalam kelas, karena kita menyesuaikan dengan karakter siswa yang mana kebanyakan siswa malas ketika dalam pembelajaran monoton di dalam kelas maka dari itu kami ajak keluar kelas agar siswa merasa bahwa pembelajaran tentangmateri bab sholat menyenangkan. Sehingga akan terbenak di dalam hati dan fikiran siswa bahwa melaksanakan kewajiban sholat itu menyenangkan karena di lakukan bisa di dalam rumah maupun di masjid sekitar. Selanjutnya kami arahkan untuk pembiasaan sholat fardhu berjamaah di masjid. Yang mana kebetulan di 
sekolah kami membiasakan para peserta didik untuk melaksanakan sholat dhuha berjamaah, dan di lanjut dengan istighosah bersama. Dalam hal ini merupakan wujud dari usaha kita agar siswa terbiasa melaksanakan kewajiban sholat dengan hal-hal yang menyenangkan bagi siswa. Namun ada juga kendala dalam proses belajar yakni menghadapi siswa yang abk (anak berkebutuhan khusus) keterlambatan siswa dalam memahami materi dari pada siswa yang lain.

Wawancara selanjutnya terhadap narasumber yang sama yaitu Ibu Delta, peneliti bertanya terkait desain pembelajaran model assure yang di gunakan oleh guru PAI pada hari itu bab ahlak terpuji bagaimana guru dalam mendesain pembelajaran tersebut yakni:

Ketika dalam proses pembelajaran seperti di kelas empat materi ahlak terpuji di dalam kelas yang mana saya ketahui bermacam-macam karakter siswa yakni ada yang nakal dan ada yang baik juga maka yang pertama saya lakukan siswa saya berikan soal yang berupa masalah terkait kesehariharian merea tentang prilaku ahlak teruji dan ahlak tercela kemudian saya suruh untuk mencontohkan ahlak yang terpuji dan ahlak yang tercela. Sesudah itu ketika sudah memasuki kelas kita bahas hasil dari tulisannya para siswa terkait soal tadi, kemudian kami bahas bersama. Dengan hal ini saya fikir akan melatih siswa untuk berfikir aktif dalam pembelajaran, dan juga agar tidak monoton guru yang menjelaskan perbedaan ahlak yang terpuji dan ahlak yang tercela.

Begitu juga hasil observasi dan wawancara yang di amati oleh peneliti dalam penerapan model assure oleh guru PAI yakni pertama, menganalisis karakter siswa seperti siswa kelas 3 MI yang mana pada tahap ini siswa masih membutuhkan kegiatan belajar yang menyenangkan sehingga di minati siswa maka guru memakai metode pemecahan masalah, demontrasi yang di anggap sesuai untuk perkembangan kognitif mereka. Dan membuat gaya belajar yang dapat memotivasi siswa. Kedua, menetapkan tujuan pembelajaran dalam hal ini guru menentukan tujuan belajar sesuai kompetensi dasar yang harus di capai siswa melalui kurikulum k13 seperti contoh siswa mampu menguraikan ahlak terpuji dan ahlak tercela. Ketiga, memilih strategi, media dan bahan ajar yang di pakai seperti contoh guru menggunakan media lingkungan sebagai contoh penerapan ahlak yang terpuji dan tercela, kemudian memakai metode diskusi yang mana setelah siswa melihat langsung fenomena yang ada terkait ahlak yang terpuji maka siswa di ajak untuk mendiskusikan tentang materi ahlak yang baik dan yang buruk. Keempat, evaluasi, dalam tahap ini guru menilai hasil belajar siswa melalui tes tugas yang di berikan guru, dan alat yang digunakan dalam pembelajaran, apakah alat tersebut efektif di gunakan dalam pembelajaran.

Dari hasil di atas maka di ketahui bahwa penggunaan desain pembelajaran model asssure sangat membantu guru dan juga peserta didik 
dalam proses pembelajaran berlangsung. Hal ini di lihat dari keaktifan siswa ketika diskusi materi pelajaran dengan kelompok dan di lihat dari keaktifan siswa dalam mengaplikasian materi yang di dapat kepada lingkungan nyata. Jadi dari hasil penelitian dapat di katakan model pembelajaran model assure efektif di gunakan dalam pembelajaran pendidikan agama islam.

Adapun terkait problema yang di hadapi ketika dalam proses pembelajaran yakni masalah pada siswa yang malas belajar dan masih membutuhkan pengawasan ekstra dari guru, dalam hal ini sebaiknya guru mata pelajaran tersebut bekerjasama dengan ahli psikolog yang lebih tau cara menangani peserta didik yang malas belajar. Karena kita ketahui meskipun memakai banyak model desain pembelajaran namun juga ada beberapa faktor yang mempengaruhi belajar peserta didik yang wajib di ketahui oleh pendidik. Seperti yang di katakan oleh slameto bahwa yang mempengaruhi belajar peserta didik ada dua yakni faktor intern dan faktor ekstern.

Pertama, faktor intern meliputi keadaan jasmani yakni keadaan kesehatan dan fisik diri siswa, keadaan psikologis siswa seperti intelegensi, minat bakat dan kesiapan siswa untuk menerima materi pelajaran, dan faktor kelelahan yang di alami siswa karena ketika siswa lelah juga akan berpengaruh terhadap hasil belajar siswa tidak akan optimal. Kedua, faktor ekstern meliputi beberapa macam di anataranya pertama, faktor keluarga karena setiap siswa akan terpengaruh oleh didikan orang tua yang mana banyak berbagai cara orang tua dalam mendidik anak, begitu juga latar belakang kebudayaan keluarga akan berpengaruh terhadap potensi yang di miliki siswa. Kedua faktor sekolah, dalam hal ini faktor sekolah mencakup beberapa komponen seperti metode, media, bahan ajar, dan model pembelajaran yang di pakai guru dalam proses belajar. Ketiga faktor masyarakat sangat berpengaruh terhadap hasil belajar siswa, karena kegiatan yang biasa di lakukan oleh masyarakat akan membentuk karakter siswa dalam bergaul dan bertingkah sesuai lingkungannya ((2010) ).

Terkait faktor-faktor tersebut guru harus bisa mengenal setiap karakter peserta didik dan kebutuhan peserta didik karena jika tidak maka akan berpengaruh negatif terhadap proses belajar anak seperti problem yang di hadapi di MI Darul Hidayah akibat kemalasan siswa tentunya di pengaruhi oleh salah satu faktor intern maupun ekstern dimana gurulah yang harus memahami hal tersebut dan mampu menangai siswa, sehingga dalam proses pembelajaran berlangsung terciptanya kegiatan belajar yang efektif dan efisien dan dapat menghasilkan hasil belajar yang optimal. 
Sedangkan terkait problema guru MI Darul Hidayah dalam menghadapi keterlambatan anak ABK dalam memahami materi pelajaran, kita ketahui bahwa anak anak abk sangat memerlukan perlakuan khusus dari guru, jadi sebaiknya guru menangani dengan pendekatan pembelajaran secara komperehensip. Pendekatan pembelajaran di bagi tiga yakni pendekatan individualistis, pendekatan kelompok, pendekatan campuran, dan lain sebagainya.

Dalam pendekatan individualistis, islam mengakui adanya perbedaan yang dimiliki manusia secara individu, dan karenanya di antara manusiamanusia itu ada yang cerdas dan ada yang bodoh, ada juga yang menjadi tukang dan ada pula yang duduk menjadi bos, dan lain sebagainya.

Allah berfirman dalam surat al-an'am ayat 165;

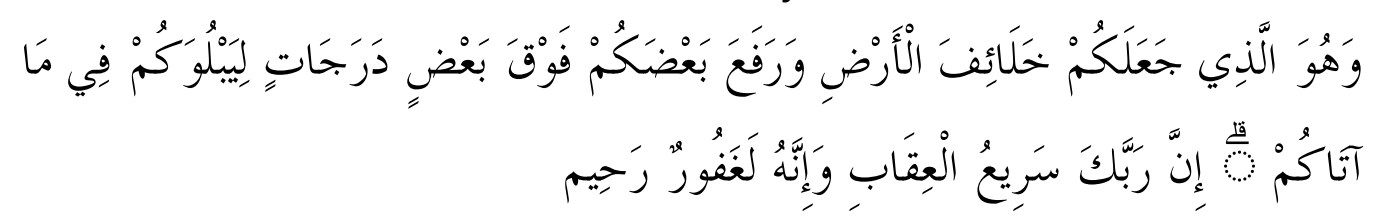

Dan dia-lah yang menjadikan kamu penguasa di bumi dan dia meninggikan sebagian kamu atas sebagian (yang lain) beberapa derajat, untuk mengujimu tentang apa yang diberikan-nya kepadamu. Sesungguhnya tuhanmu amat cepat siksaan-nya, dan sesungguhnya dia maha pengampun lagi maha penyayang.

Pendekatan ini sungguh sangat arif terhadap perbedaan masing-masing peserta didik; mulai dari gaya yang ditampilkan, perilaku yang bermacammacam, cara mengemukakan pendapat, cara berpakaian, daya serap, tingkat kecerdasan dan sebagainya (( dkk., 1997) ). oleh karenanya, melalui pendekatan individulis, sesuatu yang membuat kesulitan peserta didik dalam belajar segera akan dapat dipecahkan, karena melalui pendekatan demikian peserta didik akan menjadi pusat pembelajaran dimana masingmasing peserta didik itu sendiri mendapatkan perhatian penuh dan merata.

Pendekatan individualistis ini juga bisa disebut sebagai pendekatan yang demokratis, karena setiap pembelajar di perlakukan sesuai dengan apa yang diinginkannya. Lebih dari itu, penghargaan yang disediakan dalam pendekatan ini tentunya bermacam-macam sesuai dengan kecakapan peserta didik yang berbeda-beda. Mudahnya, pendakatan ini menyediakan peluang yang luas kepada peserta didik untuk berkembang sesuai kemampuannya; bagi peserta didik yang bersungguh-sungguh dapat melakukan belajar lebih cepat, dan sebaliknya peserta didik yang kurang bersungguh-sungguh dapat menyelesaikan pelajaran sesuai dengan kesanggupannya. 
Dalam pendekatan kelompok peserta didik tidak hanya mempunyai perbedaan-perbedaan sebagaimana dijelaskan dalam pendekatan individualistis. Di samping itu, peserta didik ternyata mempunyai perbedaan dan persamaan yang antara satudengan yang lainnya ((Abuddin, 2011) ). Dalam hal ini perbedaan itu diintegrasikan seperti seorang siswa yang pintar disatukan dengan siswa yang kurang cerdas sehingga dapat mendorong teman yang kurang cerdas tersebut. Begitu pula peserta didik yang memiliki persamaan, mereka akan sangat punya potensi untuk berkembang karena mereka sudah menemukan sinergi dengan sendirinya. Pendekatan kelompok ini juga terbangun dari asumsi bahwa setiap peserta didik mempunyai kecenderungan untuk berteman dan berkelompok ((Abuddin, 2011),h,159. ). sehingga, melalui aktivitas berteman dan berkelompok tersebut peserta didik dapat tumbuh dalam dirinya rasa sosial yang tinggi, pengendalian egoisme, dan lain-lain.

Pendekatan campuran, pendekatan ini sebenarnya merupakan gabungan dari pendekatan individualistis dan kelompok. Pendekatan ini berusaha untuk mensinergikan keunggulan yang terdapat pada pendekatan individual dan pendekatan kelompok (( dkk., 1997),h,47. ). perbedaanperbedaan yang menyertai peserta didik tentu akan sulit diselesaikan jika menggunakan satu pendekatan saja. Pendekatan campuran ini hadir guna menjadi solusi dari keterbatasan dari dua pendekatan sebelumnya, mencoba mengkolaborasikan keunggulan-keunggulan dari dua metode tersebut dan dicoba untuk diaplikasikan.

Dalam hal ini, pendekatan campuran, seorang guru dapat membagi peserta didik ke dalam beberapa kelompok belajar yang disesuaikan dengan minatnya masing-masing. Sehingga jika memang demikian, dalam sekali proses pembelajaran, akan ada dua kemungkinan; yaitu kemungkinan kelompok bagi siswa yang suka belajar berkelompok dan kemungkinan peserta didik yang belajar sendiri bagi mereka yang menyukai belajar secara mandiri. Namun, meski demikian, kesemuanya masih berada dalam pengawasan guru.

Kesimpulan sederhananya tentang pendekatan ini adalah bahwa dalam proses pembelajaran tidaklah selalu berjalan mulus, akan ada beberapa kasus-kasus masalah yang muncul dan justru masalah tersebut tidak pernah terprediksikan sebelumnya; banyak motif yang menjadikan masalah-masalah tersebut muncul ke permukaan proses pembelajaran, dan karenanya perlu adanya pendekatan campuran untuk dijadikan alat untuk menyelesaikan masalah-masalah itu (Djamarah, 67). 


\section{Kesimpulan}

1. Penggunaan desain pembelajaran model asssure sangat membantu guru dan juga peserta didik dalam proses pembelajaran berlangsung.

2. Adapun problema yang di hadapi guru di MI Darul Hidayah dalam pembelajaran yakni masalah pada siswa yang malas belajar dan masih membutuhkan pengawasan ekstra dari guru, keterlambatan anak ABK dalam memahami materi pelajaran

3. Solusi dalam menangani problema yang ada yakni sebaiknya guru mata pelajaran tersebut bekerjasama dengan ahli psikolog yang lebih tau cara menangani peserta didik yang malas belaja, dan guru harus dapat memperhatikan setiap karakter peserta didik karena dalam pembelajaran terdapat faktor-faktor yang mempengaruhi belajar peserta didik dan sebagai guru harus memperhatikan hal tersebut. Adapun mengenai keterlambatan anak ABK guru dapat melakukan pemecahan masalah tersebut dengan pendekatan pembelajaran secara komperehensip.

\section{Daftar Rujukan}

Abuddin, N. (2011). Perspektif Islam Tentang Strategi Pembelajaran (hlm. 155). Kencana.

Djamarah, Bahri, S., \& Zain, A. (1997). Strategi Belajar Mengajar (hlm. 67). PT Rineka Cipta.

Fridani, L., Wulan, S., \& Puji Astuti, S. I. (2010). Evaluasi Perkembangan Anak Usia Dini (hlm. 3-5). Universitas Terbuka.

Heinich, R., Molenda, M., Russel, J., \& Smaldino, S. (2005). Instructional Technology And Media For Learning (hlm. 114). Prentice-Hall Inc.

Hildayanti, R., Sugianto, M., Tarigan, R., Handayani, E., Pudjiati, R., \& Mary Kouri, A. (2008). Psikologi Perkembangan Anak (hlm. 15-22). Universitas Terbuka.

Jense, E. (2011). Pembelajaran Berbasis Otak Paradigma Pengajaran Baru (hlm. 160-162). Indeks.

Liu, J. (2015). College English Writing Teaching Design Based On Contructivist Mode. Journal Of Modern Linguistics, 43.

Pribadi, B. A. (2011). Model Assure Untuk Mendesain Pembelajaran Sukses. Dian Rakyat, 31.

Rougtledge. (1994). Teaching To Transgress (hlm. 41-44). Gloria Watkins.

Routledge. (2003). Teaching Community (hlm. 67-81). Gloria Watkins. 
Ning Fina Inayatus Sofa

Salamah Zainiyati, H. (2010). Model dan Strategi Pembelajaran Aktif Teori dan Praktek Pembelajaran Pendidikan Agama Islam (hlm. 67). CV. Putra Media Nusantara.

Slameto. (2010). Belajar dan Faktor-Faktor yang Mempengaruhinya (hlm. 54-60). Rineka Cipta. 